\title{
Investigation of Changes in Beach Morphology due to Coastal Armoring
}

\author{
C. Anandan ${ }^{1} \&$ C. Senthil Kumar ${ }^{1}$ \\ ${ }^{1}$ Atomic Energy Regulatory Board, India \\ Correspondence: C. Senthil Kumar, Atomic Energy Regulatory Board, India.
}

Received: April 11, 2021

Accepted: May 19, 2021

Online Published: May 21, 2021

doi:10.5539/eer.v11n1p65

URL: https://doi.org/10.5539/eer.v11n1p65

\begin{abstract}
The Tsunami, which struck the east coast of India on 26th December 2004, caused huge damage to life, property and environment. Beyond the heavy toll on human lives, it had caused an enormous environmental impact. Kalpakkam located in the south east coast of India is one of the areas affected by the tsunami. At some locations along the coast around Kalpakkam, morphological changes, vegetation loss and fatality were reported. Later, a slew of remedial measures were initiated at Kalpakkam in 2006 and construction of coastal armoring in the form of Tsunami Protection Wall (TPW) of $3.2 \mathrm{~km}$ length was one of them. A study was undertaken to assess the impact of this TPW on the surroundings based on periodic measurements of High Water Line (HWL) before and after construction of the wall. Also beach profiles were made at selected locations to observe seasonal changes in sedimentation pattern (i.e. accretion and erosion). As the residential area at Kalpakkam is located between fishing hamlets at northern and southern side, it is necessary to understand the impact of TPW, if any, in the surrounding area and on the fishing hamlets. Towards this assessment, high resolution satellite data such as Quickbird and IKONOS were employed (for the years 2002, 2003, 2009 and 2011) to measure the HWL. In addition, monthly beach profiles were carried out to measure the sedimentation pattern at selected transects with the help of N3 Precision Level survey instrument for the year 2009. The detailed investigations and analysis revealed no significant impact on the beach morphology and sedimentation patterns due to the construction of TPW, within the residential areas as well as at fishing hamlets. The average variations in the position of HWL along the coast was $4.6 \mathrm{~m}$ and sedimentation changes were in the range of $\approx 0.5 \mathrm{~m}$ in the berm of backshore region and $\approx 1.7 \mathrm{~m}$ in the swash zone of the foreshore region all along the study area. No adverse effect is observed and the variations observed are similar to that in an unarmored control beach. The study provides the confidence that multi-dated satellite monitoring together with the profiling of beach would suffice the need for understanding the changes in the beach morphology due to the construction of beach armoring.
\end{abstract}

Keywords: remote sensing, Tsunami Protection Wall, High Water Line, level survey, beach profile, beach morphology

\section{Introduction}

The shoreline changes and the beach morphology are of major concern for coastal communities as it has the potential to threaten their livelihood. Natural calamities such as Tsunami, hazardous storms, hurricanes are significant contributors to morphological changes. The Tsunami, which struck the east coast of India on 26th December 2004, brought in a huge amount of damage to life, property and environment. Beyond the heavy toll on human lives, it caused an enormous environmental impact along east coast of India. Kalpakkam located in the south east coast of India is one of the areas affected by the tsunami Ilangovan et al. (Ilangovan, Jayakumar, Gowthaman, Tirodkar, Ramana \& Naik, 2005), Verma et al. (Verma, Nair, Singh \&Sasidhar, 2006), Kumar et al. (Kumar, Naik, Ramanamurthy, Ilangovan, Gowthaman \& Jena, 2008), Anandan and Sasidhar (Anandan \& Sasidhar, 2008) leading to morphological changes, vegetation loss and loss of lives. Subsequently, extensive rehabilitation measures were taken up. The most common safety measure is construction of protection wall along the coast. Generally, such protection walls run parallel to the beach and are built with concrete, wood, steel or boulders. They are also called bulkheads or revetments or seawalls and designed to halt shoreline erosion caused primarily by wave action and to protect coastal structures from various costal hazards. One such well-designed engineered coastal armor namely Tsunami Protection Wall 
(TPW) was constructed about $3200 \mathrm{~m}$ length along the shoreline bordering the Kalpakkam residential area to meet any future exigencies.

Although seawalls are thought of as the most secure form of coastal defense, environmentalists opine that this perception needs to be balanced against the environmental problems which can be caused by their use. Improperly designed seawalls may cause impacts in front, at the ends, and behind the wall, and encompass sediments, cliffs, and ecological changes French (French, 2001). All of these impacts need to be considered in order to undertake a complete assessment of the role of seawalls in coastal defense. Failure of some seawalls and rapid erosion of the foreshore in the vicinity of some seawalls has prompted controversy as to whether seawalls protect or damage natural beaches. Coastal planners and managers become increasingly reluctant to consider these structures for their coastal defense applications. Extensive literature reviews Kraus (Kraus, 1987 \& 1988) conclude that beaches with and without seawalls exhibit similar behavior and variation with regard to short-term erosion and recovery associated with storms and post-storm wave conditions. Further, it is stated that seawalls are relatively inoffensive with regard to cross-shore sediment transport processes and only have potential to damage neighboring beaches if long shore processes are interrupted. Conflicting reports emanated over the role of seawalls on shoreline. The study carried out by US Army Engineer Waterways Experiment station Griggs et al. (Griggs, Tait, Moore, Scott, Corona \& Pembrook, 1997), Kraus (Kraus, 1988), Kraus and Rosati (Kraus \& Rosati, 1997) showed that changes in beach profiles are transitory and attributed to seasonal changes. No long term differences were observed between wall area and non-wall area. The laboratory scale experimental study carried out Hattori and Kawamata (Hattori \& Kawamata, 1997) showed that a seawall did not always produce erosion when introduced in the active wave zone of a beach. Studies Chestnutt and Schiller (Chestnutt \& Schiller, 1971) shows that maximum erosion occurred when a seawall is placed on the critical region lying in the surf zone. Waves with same properties can have vastly different impacts on the beach sediment Weggel (Weggel, 1988). From the literature study, it was observed that the sea walls have both positive and negative impact on the beach morphology based on the design and location. In this context, a study was undertaken to assess the impact of the TPW on the beach morphology at Kalpakkam and to the surroundings based on periodic measurements of the position of High Water Line (HWL) and sedimentation pattern i.e. accretion and erosion pattern. As the residential area is located between two fishing hamlets viz. Sadras Kuppam and Oyyali Kuppam at the northern and southern side respectively, it was felt necessary to understand the impact of TPW, if any, on surrounding areas and on the fishing hamlets (Fig.1). 


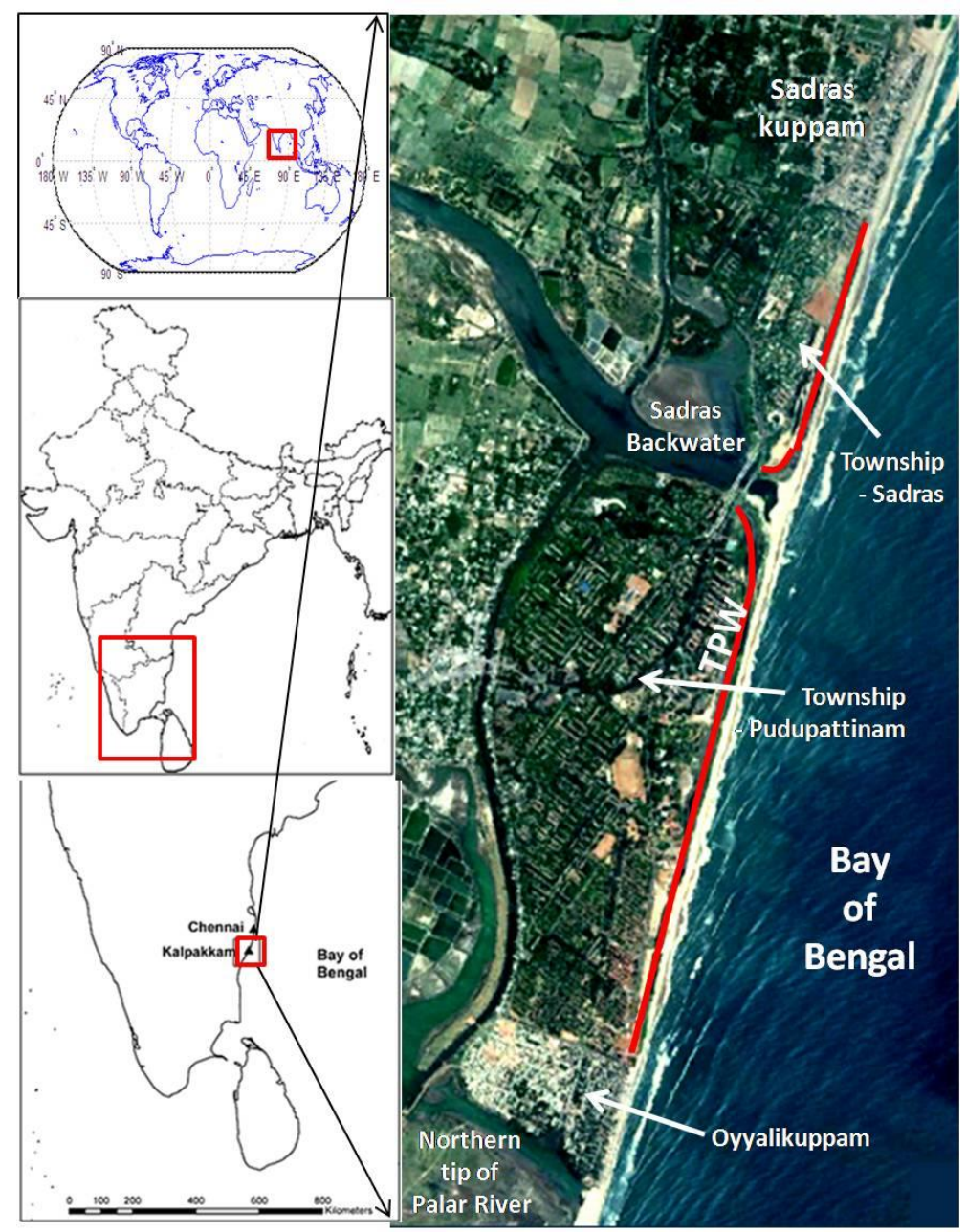

Figure 1. Study area.

\section{Beach Morphology and Tsunami Protection Wall}

The study area was a flat sandy beach characterized by isolated coastal vegetation such as casuarinas, coconut trees, scrubs, coastal grasses etc. It is flanked by a wide sandy beach which is 20 to $100 \mathrm{~m}$ in width during the summer months. During severe winters, however, waves erode the beach.

In 2006 , at $\approx 42 \mathrm{~m}$ away from the high water line, TPW was constructed with dimensions $3200 \mathrm{~m} \times 4.5 \mathrm{~m} \times$ $0.3 \mathrm{~m}$. Further, the TPW was reinforced with rubble stones with a slope of $1 \mathrm{in} 1.5$ for a distance of $4 \mathrm{~m}$ from the edge of the TPW towards sea and a sand dune with a bottom width of about $20 \mathrm{~m}$ with its centerline located at a distance of $14 \mathrm{~m}$ from the HWL (Fig.2). The wall has vegetation on either side comprising casuarinas, coconut trees, creepers, coastal grass etc. Raj et al. (Raj et al., 2006).

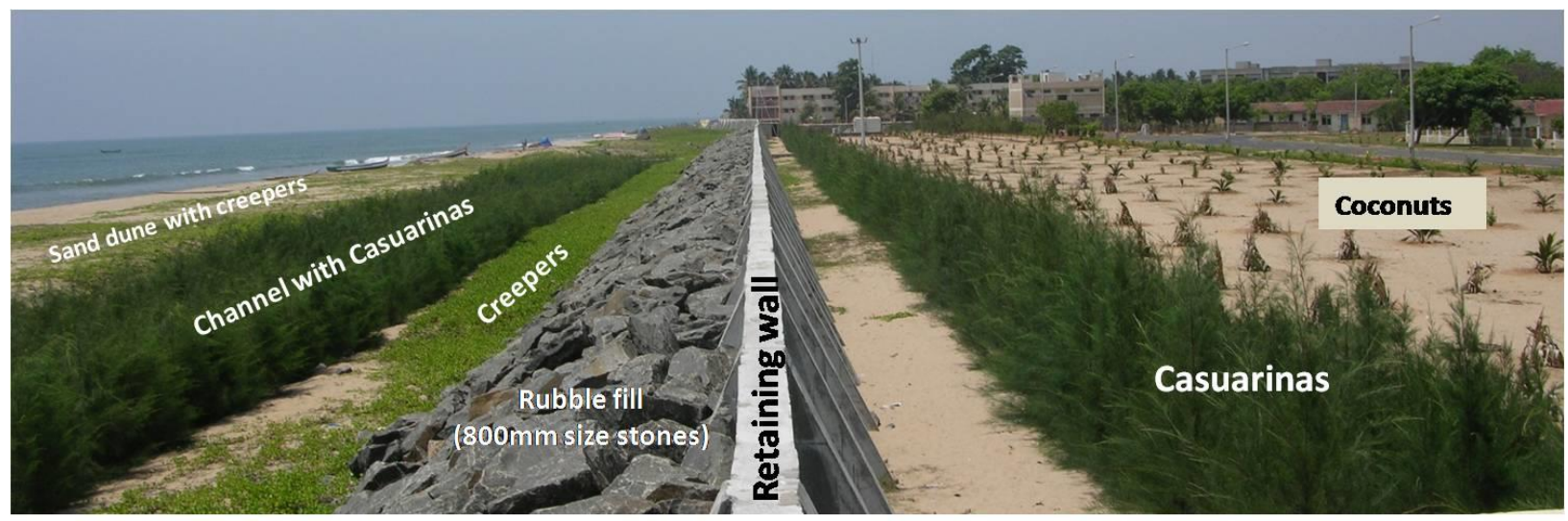

Figure 2. Typical elements of coastal armoring 


\section{Methodology}

\subsection{Mapping the Positional Change of High Water Line}

Generally, the physical interface of land and water is taken as shoreline and studied for changes in the beach Dolan et al. (Dolan et al., 1980). However, in practice, identifying shoreline is very difficult since the shoreline position changes continually through time because of cross-shore and alongshore sediment movement, dynamic nature of waves, tides, storm surge. The beach slope, tidal range, and prevailing wave/weather condition also affect shoreline position Morton (Morton, 1991). Some studies on shoreline change consider discrete transects or points and monitor how these change through time. However, there are large uncertainties involved in such sampling method, such as identifying the representative transects, the morphological feature such as beach cusps, etc. which influence the alongshore average shoreline position Boak and Turner (Boak \& Turner, 2005). To study the changes in the shoreline, satellite data is very important. However, satellite data are snap shots of land features taken at a specific time whereas the shoreline is a dynamic nature and is difficult to identify shoreline from the imagery (For eg., points a or b in Fig.3). Considering the dynamic nature of the idealized shoreline boundary, for practical purposes, scientists have typically adopted the use of shoreline indicators as a proxy to represent the true shoreline position. There are $\approx 45$ type of shoreline indicators adopted to extract the shoreline. In the present study, the most common indicator called High Water Line (HWL) is digitized as continuous line feature using GIS software by visually identifying the dry-wet boundary Dolan et al. (Dolan et al., 1980), Fisher and Overton (Fisher \& Overton, 1994), Hapke and Richmond (Hapke \& Richmond, 2000). The multi dated satellite data are geo-rectified and all images were projected into Universal Transverse Mercator geographic co-ordinates to identify the exact physical locations in the study area. Separate shape files are created for TPW with HWL demarked using onscreen digitization method by employing GIS software. The study area has been segmented into 21 parts and the distance between TPW and HWL, $\left(\mathrm{D}_{t w l-h w l}\right)$ are measured using the GIS software. 


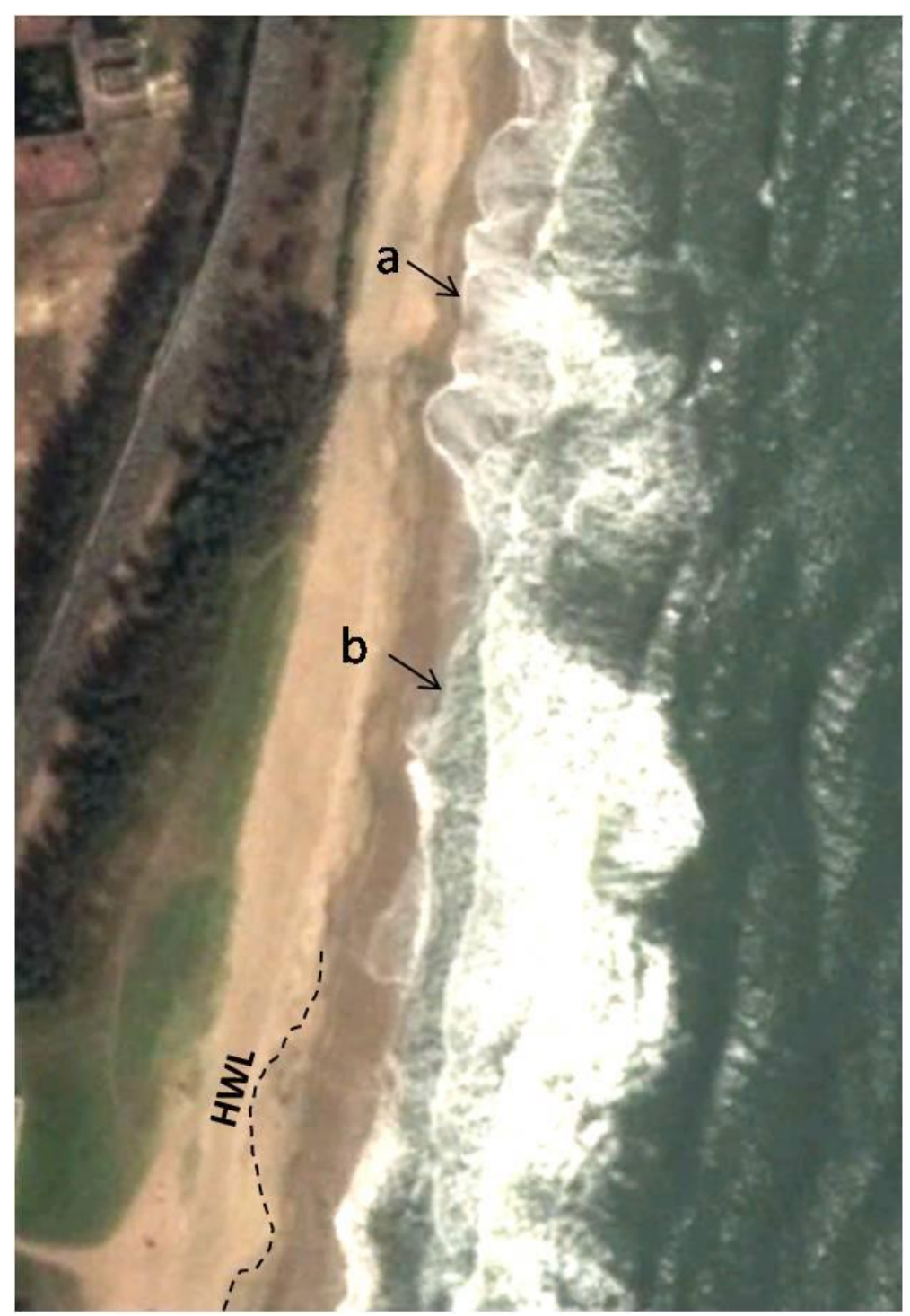

Figure 3. High Water Line used in the study

\subsection{Beach Profile}

A base reference station is established by employing real-time kinematic GPS. With this base station, seven reference benchmarks are established in front of the wall area. Monthly field survey was carried out during 2009 to measure the sedimentation pattern at reference benchmarks with the help of N3 precision level survey instrument, a measuring tape and a standard measuring staff (Fig.4). The beach profiling was carried out along shore-normal direction from the reference benchmark to HWL, $\left(\mathrm{D}_{t w l-h w l}\right)$. These profiles were then compared to ascertain the change in the beach width with respect to seasons. 


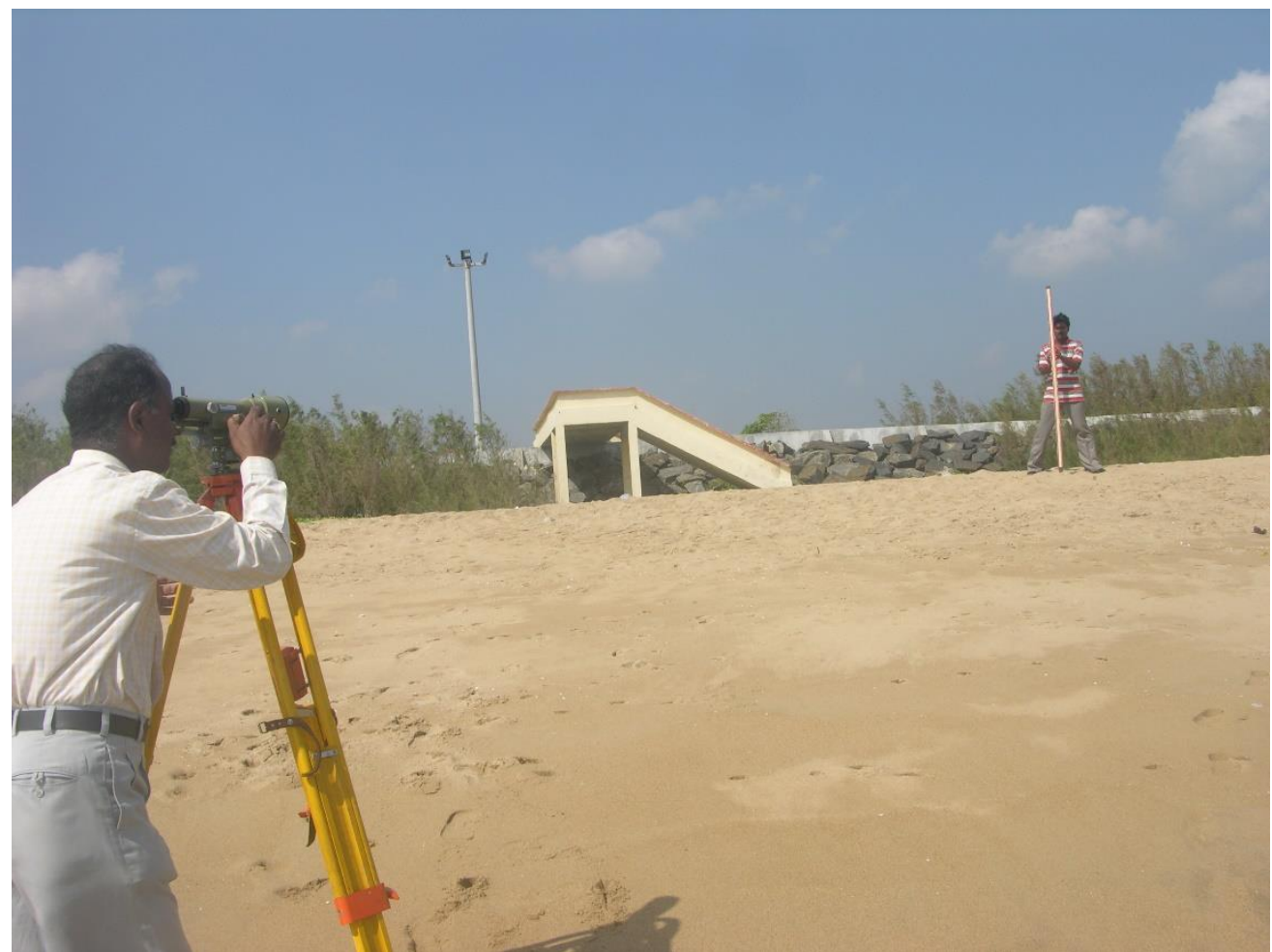

Figure 4. Beach profile using N3 precision level instrument

\subsection{Data Used}

High resolution satellite data such as Quickbird and IKONOS were employed (for the years 2002, 2003, 2009 and 2011) to monitor the change in $\mathrm{D}_{t w l-h w l}$ (Table 1).

Table 1. Data used in the study

\begin{tabular}{ccc}
\hline \multicolumn{2}{c}{ HWL } & \\
\hline $\begin{array}{c}\text { Year of } \\
\text { acquisition } \\
\text { Pre-construction of TPW } \\
2002\end{array}$ & Data & Resolution \\
2003 & IKONOS & 1m (PAN) \\
Post-construction of TPW & Quickbird & $.61 \mathrm{~m}$ \\
2009 & Quickbird & $.61 \mathrm{~m}$ \\
2011 & Quickbird & $.61 \mathrm{~m}$ \\
& Beach Profile & \\
Year of Survey & Instrument & Vertical \\
& & Precision \\
2009 & N3 Precision Level & mm
\end{tabular}

\section{Results and Discussion}

\subsection{Change in the Position of High Water Line}

In the present study, the period of tsunami (2004) and the period of construction of TPW (2005-2008) are not considered so as to avoid their influence in the results. The change in the position of HWL, $\mathrm{D}_{t w l-h w l}$ is compiled for four years including the pre-construction $(2002,2003)$ and post-construction $(2009,2011)$ periods (Fig.5). 
There is no uniform trend in the position of HWL in the segments i.e. in some segments it shows landward movement whereas in other segments a seaward movement is observed for the same year. This type of variation is observed for all years. The position of HWL in 2003 and 2004 was averaged and taken up as the position of HWL during the pre-construction period. Similarly, the HWL in 2009 and 2011 was averaged and taken up as the position of HWL during the post-construction period. By comparing these two HWLs, it was found that the average difference between the position of HWL in pre- and post- construction period is $4.6 \mathrm{~m}$ (Fig.6, Table 2). The negative sign of the difference shows erosion trend. The average erosion rate of Kalpakkam coast was calculated as $0.46 \mathrm{my}^{-1}$. This value closely matches with the earlier prediction i.e. $0.55 \mathrm{my}^{-1}$ NIOT (NIOT, 2009). In the study area, it is observed that three segments located very close to backwater/river mouth show significant difference in the position of HWL. The high rate of erosion along these locations is due to the interception of northward moving littoral currents by the river flows. These types of erosion behavior are common along the East Coast of India where the net littoral drift is towards north Rao et al. (Rao, Murthy, Bhat \& Reddy, 2009). The pre- and post- construction period position of HWL, clearly indicates that the response of beach is uniform along armored and unarmored beach as the TPW was constructed $\approx 40$ meters away from the HWL. 


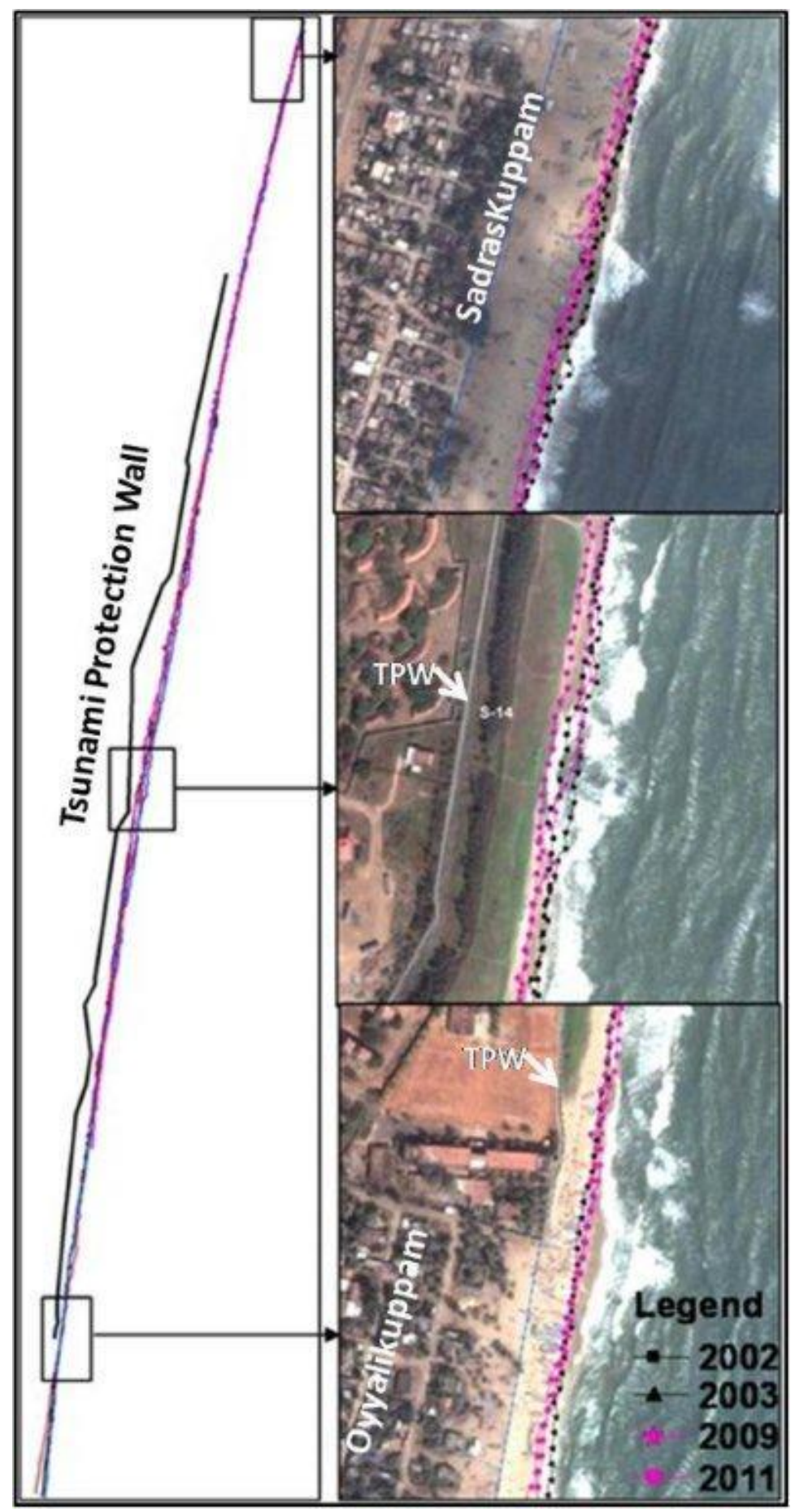

Figure 5. Variations in the position of High Water Line (at selected segments) 


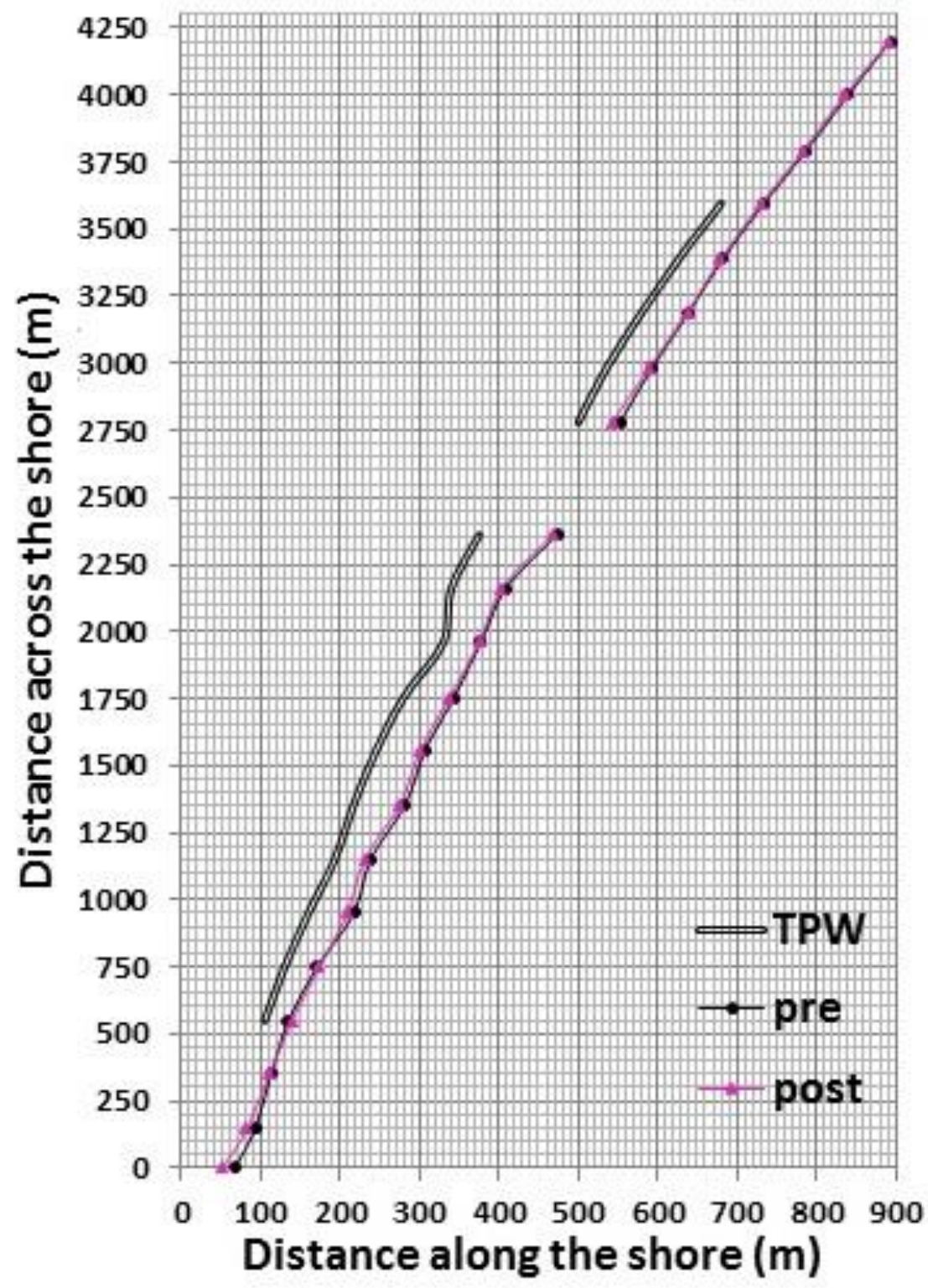

Figure 6. Comparison of HWL (pre- and post- construction of TPW) 
Table 2. Distance between reference BM and HWL during pre- and postconstruction of the TPW

\begin{tabular}{cccc}
\hline \multirow{2}{*}{ Segment } & \multicolumn{3}{c}{$\mathrm{D} t p w-h w l(\mathrm{~m})$} \\
\cline { 2 - 4 } pre $^{\mathrm{a}}$ & \multicolumn{2}{c}{ post $^{\mathrm{b}}$ Difference } \\
\hline 1 & 48.3 & 47.6 & -0.6 \\
2 & 50.0 & 45.6 & -4.4 \\
3 & 51.6 & 48.3 & -3.4 \\
4 & 53.8 & 50.6 & -3.1 \\
5 & 55.5 & 52.8 & -2.8 \\
6 & 59.4 & 57.4 & -2.0 \\
7 & 57.5 & 53.8 & -3.8 \\
8 & 52.9 & 42.6 & -10.3 \\
9 & 98.3 & 92.8 & -5.5 \\
10 & 68.6 & 63.9 & -4.8 \\
11 & 47.6 & 45.4 & -2.3 \\
12 & 63.5 & 58.3 & -5.3 \\
13 & 61.9 & 55.8 & -6.1 \\
14 & 65.1 & 58.4 & -6.8 \\
15 & 45.4 & 38.0 & -7.4 \\
16 & 57.5 & 48.9 & -8.6 \\
17 & 41.0 & 44.3 & 3.3 \\
18 & 30.0 & 34.1 & 4.1 \\
19 & 23.0 & 20.8 & -2.3 \\
20 & 32.5 & 22.5 & -10.0 \\
21 & 42.5 & 26.8 & -15.8 \\
\hline
\end{tabular}

${ }^{\text {a Averaged }} \mathrm{D}_{t p w-h w l}$ of $2002 \& 2003$

${ }^{\mathrm{b}}$ Averaged $\mathrm{D}_{t p w-h w l}$ of $2009 \& 2011$

\subsection{Changes in the Sedimentation Pattern}

To monitor the variation in the sedimentation pattern, monthly field survey was carried out during 2009 by employing precision N3 survey instrument. Seven profiles (P1-P7) were drawn to know the changes in the cross shore beach morphology (Fig.7, Table 3). The one year profiling of beach indicate that average sedimentation changes is $\approx 0.5 \mathrm{~m}$ in the berm of backshore region and $\approx 1.7 \mathrm{~m}$ in the swash zone of the foreshore region all along the study area and is similar for armored beach and unarmored control beach (Table 3). From the seven profiles, it is evident that significant difference in sedimentation pattern is limited to swash zone of foreshore region. The decrease in berm was observed during pre-monsoon (Mar-May) to onset of south west monsoon (Jun-Sept) where the increase in berm was observed throughout the monsoon period which indicates the strong influence of wave action. The profiling of beach also indicated no induced change in the sedimentation pattern all along armored and unarmored area (Fig.7). The observed variation in the accretion/erosion of the sediment is insignificant. 
Table 3. Seasonal variation in the elevation of berm height

\begin{tabular}{cccccc}
\hline Profile & \multicolumn{5}{c}{ Berm elevation } \\
& $\begin{array}{c}\text { Increase } \\
(\mathrm{m})\end{array}$ & Month & $\begin{array}{c}\text { Decrease } \\
(\mathrm{m})\end{array}$ & Month & $\begin{array}{c}\text { Difference } \\
(\mathrm{m})\end{array}$ \\
\hline P1 & 2.4 & Sept. & 1.3 & Jan. & 1.1 \\
P2 & 1.7 & October & 0.9 & May & 0.8 \\
P3 & 2.6 & October & 1.0 & July & 1.6 \\
P4 & 3.1 & August & 1.0 & June & 2.1 \\
P5 & 2.7 & October & 1.1 & July & 1.6 \\
P6 & 2.8 & August & 0.9 & July & 1.9 \\
P7 & 2.5 & August & 0.5 & March & 2.0 \\
\hline
\end{tabular}

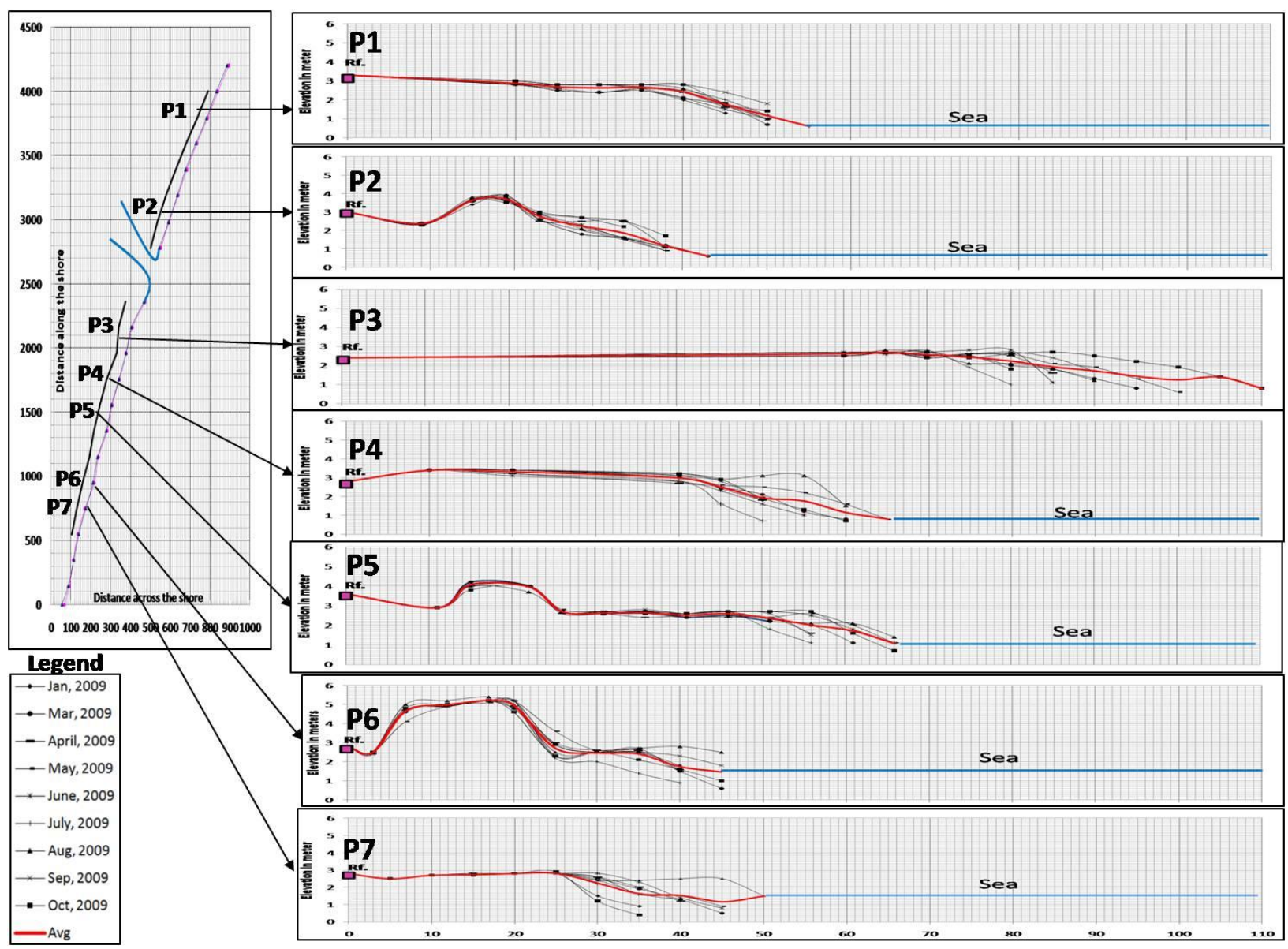

Figure 7. Sedimentation patter (accretion/erosion) observed in the study area

\section{Conclusions}

A study carried out to assess the impact of construction of a coastal armoring in the form of Tsunami Protection Wall on the beach environment is reported.

The detailed investigations and analysis revealed no significant impact on the beach morphology and sedimentation patterns due to the construction of TPW, within the residential areas as well as at fishing hamlets. The assessment is carried out based on periodic measurements of High Water Line during pre- and post-construction of the protection wall. Also beach profiles were made at selected locations to know any 
significant change in sedimentation pattern (i.e. accretion and erosion) with respect to seasons. The average variation in the position of HWL between pre- and post- construction of the TPW along the coast is $4.6 \mathrm{~m}$ and changes in the accretion/erosion pattern is $\approx 0.5 \mathrm{~m}$ in the berm of backshore region and $\approx 1.7 \mathrm{~m}$ in the swash zone of the foreshore region. The beach profiles also show that the changes in the beach width are transitory and attributable to seasonal changes only. The positional variations in HWL and the sedimentation pattern occur in uniform manner all along armored beach and unarmored control beach. It was observed that there is no lowering of beach profile or toe scour caused by wave attack or down drift flanking and up drift accretion. After the construction of the coastal armor no accelerating or enhanced beach erosion is observed because the armoring was constructed well beyond the active zone of the beach environment. There is no significant impact in front, behind and at both ends of the armoring. The present study also indicates that if a coastal armoring is properly located from the HWL, it should not cause or trigger beach erosion.

\section{Acknowledgements}

Authors wish to acknowledge the extensive help rendered by P. Rajasekar, Quality Assurance Division, IGCAR, Kalpakkam during the field survey covering a huge distance of the study area.

\section{References}

Anandan, C., \& Sasidhar, P. (2008). Assessment of the impact of the tsunami of december 26, 2004 on the nearshore bathymetry of the kalpakkam coast, east coast of india. Science of Tsunami Hazards, 27(4), 26-35.

Anandan, C., \& Sasidhar, P. (2011). Changes in coastal morphology at kalpakkam, east coast, india due to 26 december 2004 sumatra tsunami. Geomatics, Natural Hazards and Risk, 2(2), 183-192, First published on: 04 May 2011. https://doi.org/10.1080/19475705.2010.532976

Boak, E. H., \& Turner, I. L. (2005). Shoreline definition and detection: A review. Journal of Coastal Research, 688-703. https://doi.org/10.2112/03-0071.1

Chestnutt, C. B., \& Schiller, R. E. (1971). Scour of simulated gulf coast sand beaches due to wave action in front of seawalls and dune barriers. COE report 139, TAMU-SG-71-207, Texas A and M University. https://doi.org/10.4043/1352-MS

Dolan, R., Hayden, B. P., May, P., \& May, S. K. (1980). The reliability of shoreline change measurements from aerial photographs. Shore and Beach, 48(4), 22-29.

Fisher, J. S., \& Overton, M. F. (1994). Interpretation of shoreline position from aerial photographs. Proceedings of the 24th International Conference on Coastal Engineering (Kobe, Japan), 1998-2003.

French, P.W. (2001). Coastal defences: Processes, problems and solutions. Routledge, London, U. K. https://doi.org/10.4324/9780203187630

Griggs, G. B., Tait, J., Moore, L. J., Scott, K., Corona, W.W., \& Pembrook, D. (1997). Interaction of seawalls and beaches: Eight years of field monitoring, monterey bay, california. Contract Report CHL-97-1, U.S. Army Engineer Waterways Experiment Station, 3909 Halls Ferry Raod, Vicksburg, pg41.

Hapke, C., \& Richmond, B. M. (2000). Monitoring beach morphology changes using small-format aerial photography and digital softcopy photogrammetry. Environmental Geosciences, 7(1), 32-37. https://doi.org/10.1046/j.1526-0984.2000.71001.x

Hattori, M., \& Kawamata, K. (1997). Experimental on restoration of beaches backed by seawalls. coastal engineering in japan. Japan Society of Civil Engineers, 20, 55-68. https://doi.org/10.1080/05785634.1977.11924248

Ilangovan, D., Jayakumar, S., Gowthaman, R., Tirodkar, G., Ramana, M., \& Naik, K. A. (2005). Inundation, runup heights, cross-section profiles and littoral environment along the tamil nadu coast after 26th december 2004 tsunami. Technical Report, NIO/TR-03/2005, National Institute of Oceanography, Goa, India, 71.

Kraus, N. C. (1987). The effects of seawalls on the beach: A literature review. Proceedings of the Coastal Sediments 87, American Society of Civil Engineers, 945-960.

Kraus, N. C. (1988). The effects of seawalls on the beach: An extended literature review. Special Issue No.4, Journal of Coastal Research, 1-28.

Kraus, N. C., \& Rosati (1997). Interpretation of shoreline position data for coastal engineering analysis. Coastal Engineering Technical Note (CETN II-39). Vicksburg, Mississippi: US Army Waterways 
experiment station. https://doi.org/10.21236/ADA591274

Kumar, S. J., Naik, K. A., Ramanamurthy, M. V., Ilangovan, D., Gowthaman, R., \& Jena, B. (2008). Posttsunami changes in the littoral environment along the southeast coast of india. Journal of Environmental Management Volume, 89(1), October 2008, 35-44. https://doi.org/10.1016/j.jenvman.2007.01.050

Morton, R. A. (1991). Accurate shoreline mapping: past, present, and future. Proceedings of the Coastal Sediments '91 (Seattle, Washington), 997-1010.

NIOT (2009). Report on use of satellite data for detection of violation of land use along the coastal regulation zone and impact of port structures on shoreline changes. Report submitted to MoEF. October, 2009, 60.

Raj, B., Kumar, P., Krishnamurthy, S., Chetal, S., P. Swaminathan, Manjunatha, Y., \& Pillai, C. S. (2006). Management of tsunami at kalpakkam: Current status and plan, the great indian ocean tsunami of 2004 - an overview of a national disaster. National Institute of Advanced Studies, Bangalore, 124-139.

Rao, V. R., Murthy, M. R., Bhat, M., \& Reddy, N. (2009). Littoral sediment transport and shoreline changes along ennore on the southeast coast of india: Field observations and numerical modeling. Geomorphology, 112, 158-166. https://doi.org/10.1016/j.geomorph.2009.05.015

Verma, U. S. P., Nair, G. J., Singh, R. K., \& Sasidhar, P. (2006). 26th december 2004 tsunami: A geo-scientific perspective. Proceedings of Indian Ocean Tsunami - Its impact assessment and Lessons for the future, Anna University.

Weggel, J. R. (1988). Seawalls: the need for research, dimensional considerations, and a suggested classification. Journal of Coastal Research SI 4, 29-36.

\section{Copyrights}

Copyright for this article is retained by the author(s), with first publication rights granted to the journal.

This is an open-access article distributed under the terms and conditions of the Creative Commons Attribution license (http://creativecommons.org/licenses/by/4.0/). 